\title{
Prevalence of cdtABC genes encoding cytolethal distending toxin among Haemophilus ducreyi and Actinobacillus actinomycetemcomitans strains
}

\author{
H. J. AHMED, L. A. SVENSSON, L. D. COPE*, J. L. LATIMER*, E. J. HANSEN*, K. AHLMAN, \\ J. BAYAT-TURK, D. KLAMER and T. LAGERGÅRD
}

Department of Medical Microbiology and Immunology, University of Göteborg S-413 46 Göteborg, Sweden and ${ }^{*}$ Department of Microbiology, Southwestern Medical Center, University of Texas, Dallas, USA

\begin{abstract}
The aim of this study was to investigate the presence of the three $c d t A B C$ genes responsible for production of cytolethal distending toxin (CDT) in Haemophilus ducreyi and Actinobacillus actinomycetemcomitans strains. Of $100 \mathrm{H}$. ducreyi strains from the culture collection of the University of Göteborg (CCUG), 27 strains with low or intermediate cytotoxic titre $\left(<1\right.$ in $\left.10^{4}\right)$ and 23 of the remaining isolates with a high cytotoxic titre $\left(\geqslant 1\right.$ in $\left.10^{4}\right)$ were selected. Twenty-nine strains of $H$. ducreyi were isolated recently from patients with chancroid and $50 \mathrm{~A}$. actinomycetemcomitans strains from patients with periodontitis. The cytotoxic activity on HEp-2 cells and the presence of cdtABC genes were studied by cytotoxicity assay of bacterial sonicates and PCR with primers specific for individual $c d t A, B$, and $C$ genes of $H$. ducreyi in bacterial DNA preparations, respectively. All strains that manifested a cytotoxic titre in sonicate $\geqslant 1$ in 100 possessed all the three $c d t$ genes. Eighteen of the 50 strains selected from the culture collection were negative and 32 positive for $c d t$ genes. As all strains with a high cytotoxic titre gave positive PCR results, it can be assumed that the remaining 50 strains, which have high cytotoxic titre, would have been positive as well. Thus, it can be estimated that $82 \%$ of the culture collection strains had $c d t A B C$ genes. Similarly, 24 $(83 \%)$ of 29 recent $H$. ducreyi isolates expressed the CDT activity and displayed all cdtABC genes. Forty-three $(86 \%)$ of 50 strains of the closely related $A$. actinomycetemcomitans, expressing a cytotoxic activity $\geqslant 1$ in 100 , also possessed all three genes. Furthermore, the nucleotide sequence of the $c d t A B C$ genes was highly conserved among $H$. ducreyi strains from different geographic areas. These results indicate that the majority of pathogenic $H$. ducreyi and A. actinomycetemcomitans strains express a CDT activity encoded by all three $c d t A B C$.
\end{abstract}

\section{Introduction}

Haemophilus ducreyi causes chancroid, a sexually transmitted disease characterised by soft, painful, slowly healing genital ulcers [1-4]. Renewed attention has been focused on $H$. ducreyi since genital ulceration has been associated with HIV transmission in developing countries $[5,6]$. H. ducreyi produces a cytotoxin that belongs to the cytolethal distending toxin (CDT) family. The $H$. ducreyi cytolethal distending toxin (HdCDT) has been shown to inhibit proliferation, induce cell enlargement and cause death of a number

Received 29 Nov. 2000; revised version received 15 March 2001; accepted 28 March 2001.

Corresponding author: $\operatorname{Dr}$ T. Lagergård (e-mail: teresa. lagergard@microbio.gu.se). of human cells and cell lines, e.g., HEp-2, HeLa, HaCaT, T cells, B cells and human fibroblasts [7-13]. It has been shown to induce a cell cycle arrest not only in the $\mathrm{G} 2 / \mathrm{M}$ phase, but also in the $\mathrm{G} 1$ phase $[14,15]$. $c d t$ genes have also been identified in strains of Escherichia coli [16-18], some Shigella [19], Campylobacter [20-22] and Helicobacter [23] species and in the oral pathogen Actinobacillus actinomycetemcomitans [24-26]. All these toxins are encoded by an operon consisting of three genes $(c d t A B C)$, the products of which have molecular masses of $c .25$, 30 and $20 \mathrm{kDa}$, respectively $[10,14] . \quad H$. ducreyi $c d t A B C$ genes encode proteins that closely resemble those comprising the CDT of $A$. actinomycetemcomitans, which also belongs to the family Pasteurellaceae and is involved in the pathogenesis of human periodontal disease. The amino acid identity between the 
CDTs from these two species is $91 \%, 96 \%$ and $94 \%$ for the $c d t A, B$ and $C$, respectively $[24,26]$. The functions of the individual CDT proteins have not been clearly established, but all three genes are necessary for the expression of cytotoxicity [13]. Recently, the $c d t B$ gene product was reported to have a DNAase activity [27-29], which correlates well with the effect of CDTs on cell cycle progression. To date, the exact contribution of CDTs to pathogenesis has not been determined, although a correlation has been reported between the level of CDT expressed by $S$. dysenteriae and the amount of diarrhoea produced in a suckling mouse model [17]. Recently, a direct pathological effect of CDT was shown in Campylobacter jejuni; strains carrying a mutation in $c d t B$ displayed impaired invasiveness in immunodeficient mice [30]. On the other hand an isogenic $c d t C$ mutant of $H$. ducreyi was shown to be as virulent as its parent strain in the temperaturedependent rabbit model of experimental chancroid [31] and a CDT mutant retained the capacity to cause pustules in human volunteers [32]. The majority of $H$. ducreyi strains (89\%) have been reported to exert cytotoxic activity on HEp-2 cells [33]; however, the prevalence of the $c d t A B C$ genes in $H$. ducreyi and in $A$. actinomycetemcomitans and correlation with cytotoxicity have not been studied.

The aim of this study was to investigate the cytotoxicity and prevalence of the $c d t A, B$ and $C$ genes of $H$. ducreyi and A. actinomycetemcomitans isolates.

\section{Materials and methods}

\section{Bacterial strains and culture conditions}

Fifty of $100 \mathrm{H}$. ducreyi strains used in a previous study [33], isolated from different parts of the world during 1950-1991 and placed in the Culture Collection of the University of Göteborg, (CCUG) were re-examined. These strains were selected as follows: 27 of the 100 strains, which manifested a low or intermediate cytotoxic titre $\left(<1\right.$ in $\left.10^{4}\right)$, and 23 strains, which represented the remaining $H$. ducreyi isolates with a high cytotoxic titre $\left(\geqslant 1\right.$ in $\left.10^{4}\right)$. The reference strains of $H$. ducreyi used in the previous studies, i.e., 35000, CCUG 4438 (CIP 542), CCUG 4436 (CIP A76) and CCUG 7470 (CIP 76118), were included. A further 29 $H$. ducreyi strains that had recently been isolated from patients with chancroid were also investigated. Twentyfour strains were isolated during 1997 from patients with genital ulceration diseases (GUD) visiting the City Health STD Clinic in Durban, South Africa and kindly provided by Professor W. Sturm. Five strains were isolated from a similar group of patients visiting the Kiwanja Mpaka and Igawilo Health Centers in Mbeya, Tanzania in March 1999. The identity of all these clinical isolates had been confirmed by PCR. Fifty strains of $A$. actinomycetemcomitans, isolated recently from patients with periodontitis, were obtained from
Professor Gunnar Dahlén, Department of Oral Microbiology, Odontology Faculty, University of Göteborg.

$H$. ducreyi and A. actinomycetemcomitans were grown on chocolate agar plates (GLV) containing brain heart infusion (BHI) agar $5 \%$, horse blood $1 \%$, horse serum $1.5 \%$, yeast autolysate $0.06 \%$, IsoVitaleX $0.015 \%$ and vancomycin $3 \mu \mathrm{g} / \mathrm{ml}$ at $33^{\circ} \mathrm{C}\left(H\right.$. ducreyi) or $37^{\circ} \mathrm{C}(A$. actinomycetemcomitans) for $48 \mathrm{~h}$, as described previously $[7,10]$.

\section{Sonic preparation and DNA extraction}

Strains cultivated on solid medium were sonicated, as described for $H$. ducreyi [7], or suspended in sterile distilled water, vortex mixed for $10 \mathrm{~s}$ with glass beads, boiled for $10 \mathrm{~min}$ and centrifuged at $3000 \mathrm{~g}$ for $5 \mathrm{~min}$. The supernate was removed and stored at $-20^{\circ} \mathrm{C}$ until required.

\section{Cytotoxic assay}

The cytotoxic activity of sonicates was tested with 24-h, $20-30 \%$ confluent monolayers of HEp-2 cells, as described previously $[7,10]$. The cytotoxic titre was expressed as the dilution that gave $\leqslant 50 \%$ of cell growth as compared with control (phosphate-buffered saline, PBS).

\section{PCR}

The identities of all $H$. ducreyi strains were confirmed by a modified version of a previously described PCR assay [34]. The primers used were the $H$. ducreyi $16 \mathrm{~S}$ rRNA-specific sequence RPI 5'-CCCCTTTGCAGG TTTGCCGCCCTC-3', positions 1207-1230 and the non-specific sequence U3 5'-GTGCCTGCAGCCGC GGTAAT-3', corresponding to base positions 515-534 of the highly conserved U3 region of Escherichia coli 16S rRNA, to amplify a 758-bp fragment. The primers used to amplify individual $c d t A B C$ genes from the DNA of $H$. ducreyi strains are summarised in Table 1. For $c d t A$, primers 7 and 13 were used to amplify a 694bp DNA fragment; for $c d t B$, primers 12 and 8 were used to amplify a 863-bp DNA fragment; and for $c d t C$, primers 1 and 4 were used to amplify a 593-bp DNA fragment (Innovagen AB, Lund, Sweden). The identity of the PCR products has been confirmed by sequencing, cloning and recombinant expression (unpublished observations and [29]). PCR was performed with $5 \mu \mathrm{l}$ of the extracted DNA in $50 \mu \mathrm{l}$ reaction mixtures containing $50 \mathrm{mM} \mathrm{KCl}, 10 \mathrm{mM}$ Tris- $\mathrm{HCl} \mathrm{pH}$ 8.3, $1.5 \mathrm{mM} \mathrm{MgCl}_{2}, 2.5 \mathrm{U}$ Taq polymerase, $0.2 \mathrm{mM}$ of each deoxyribonucleoside triphosphate (dNTP) (Promega, Madison, WI, USA) and $10 \mu \mathrm{M}$ of each primer. The amplification cycle comprised 28 cycles denaturation at $94^{\circ} \mathrm{C}$ for $2 \mathrm{~min}$, annealing at $65^{\circ} \mathrm{C}$ for $1 \mathrm{~min}$ and extension at $72^{\circ} \mathrm{C}$ for $2 \mathrm{~min}$. The PCR products were visualised by gel electrophoresis on an agarose $1 \%$ gel (DNA grade, Labora, Sweden) followed by staining 
Table 1. Primers used in the PCR for the $c d t A, B$ and $C$ genes.

\begin{tabular}{llc}
\hline Name & Oligonucleotide sequence & $\begin{array}{c}\text { Position in respective } \\
c d t \text { gene }\end{array}$ \\
\hline$C d t A-7$ & $5^{\prime}-G G G, G G A, C T A, G T G, G A T, G G A, T C T, A A G, G A G, A G A$, TAT,AAT,G-3' \\
$C d t A-13$ & $5^{\prime}-G G G, G G A, G C T, C T T, A A T, T A A, C C G, C T G, T T G, C T T, C T A, A T A, C A G-3^{\prime}$ & $497-523$ \\
$C d t B-12$ & $5^{\prime}-G G G, G G A, A T T, C T A, A G G, A G T, T T A, T A T, G C A, A T G$, GGT,AAA,G-3' & $1190-1163$ \\
$C d t B-8$ & $5^{\prime}-G G G, G G G, A G C, T C$ T,TAG,CGA,TCA,CGA,ACA,AAA, CTA,ACA,G-3' \\
$C d t C-1$ & $5^{\prime}-G G G, G G G, A A T, T C$ T,AGT,TTT,GTT,CGT,GAT,CGC, TAA,GGA,G-3' \\
$C d t C-4$ & $5^{\prime}-G G G, G G A, C T A, G T T, A G C, T A C, C C T, G A T, T T C, T T C$, GCA,CCG-3' & $2058-2032$ \\
\hline
\end{tabular}

Sequences are expressed from $5^{\prime}$ to $3^{\prime}$ and base positions are according to Cope et al. [10]. The bases in italics represent non-homologous leader sequences carrying the restriction sites used for cloning.

with ethidium bromide and illumination with ultraviolet light.

\section{Southern blot}

Chromosomal DNA purified from $14 \mathrm{H}$. ducreyi strains with no or low cytotoxic titre was digested to completion with AvaI. These digests were resolved by agarose gel electrophoresis, transferred to nitrocellulose, and probed in Southern blot analysis as described previously [35]. The $c d t A$-specific DNA probe was prepared by using the oligonucleotide primers P3 and P6 [10] to amplify a 495-bp fragment of the $c d t A$ gene from $H$. ducreyi strain 35000 chromosomal DNA. The 460-bp $c d t B$-specific probe and the 518-bp $c d t C$-specific probe were similarly amplified with the oligonucleotide primers P10-P12 and P14-P18, respectively [10].

\section{Nucleotide sequence analysis of cdtABC genes of H. ducreyi}

PCR was used to amplify the $c d t A B C$ gene cluster from four strains of $H$. ducreyi that expressed CDT activity. These included strain CCUG 7470 (isolated in France from an Algerian patient), strain 181 (isolated in Nairobi, Kenya), strain WPB506 (isolated in West Palm Beach, CA, USA) and strain PU1 (isolated in Bangkok, Thailand). PCR was accomplished with purified chromosomal DNA and Taq DNA polymerase (Promega Corp., Madison, WI, USA) according to the manufacturer's recommendations. The oligonucleotide primers used to amplify the $c d t A B C$ gene cluster were P1 5'CCTTGTAGATTATTCACCGTC-3' and P18 5'-ACCC TGATTTCTTCGCAC-3' [10]. Nucleotide sequence analysis was performed with Big Dye Terminator chemistry and a model 373A automated DNA sequencer (Applied Biosystems, Foster City, CA, USA).

\section{Results}

Prevalence of cdtABC genes and cytotoxic activity of $H$. ducreyi strains

The PCR employed for verification of $H$. ducreyi species with the RPI and U3 primers to amplify the 16SrRNA gene showed that all strains tested were $H$. ducreyi.
The PCR technique was used to detect the three individual $c d t A, c d t B$ and $c d t C$ genes in the 50 selected strains of $H$. ducreyi. All three genes were detected in 32 of these 50 selected $H$. ducreyi strains; in the remaining 18 strains, all three genes were missing. The PCR results are exemplified by Fig. 1. All strains with a cytotoxic titre $<1$ in 100 had no detectable $c d t A B C$ genes. As the remaining $50 \mathrm{H}$. ducreyi strains (published previously) manifested a high $\left(>1\right.$ in $\left.10^{4}\right)$ cytotoxic titre in the sonicate, it can be estimated that 82 of 100 strains of $H$. ducreyi in the culture collections express CDT activity. The results are summarised in Table 2.

To confirm whether or not $H$. ducreyi strains that either expressed no CDT activity or had very low toxin titres $(<1$ in 100) possessed the $c d t A B C$ gene cluster, a Southern blot analysis was performed with $c d t A-, c d t B-$ and $c d t C$-specific probes against $10 \mathrm{H}$. ducreyi strains with very low cytotoxic titres. Four strains (35000, $7470,87067,29822$ ) that readily expressed CDT activity were included as positive controls. The 10 strains with very low toxic activity did not bind $c d t A$, $c d t B$ or $c d t C$ probes, whereas the four control strains bound all three $c d t$-specific probes (not shown).

Among the $29 \mathrm{H}$. ducreyi strains isolated recently from

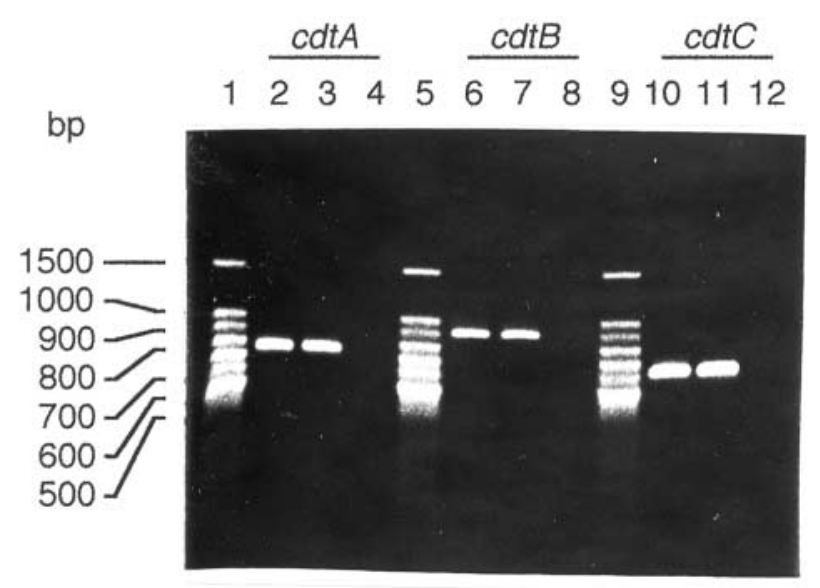

Fig. 1. Detection of individual $c d t A, c d t B$ and $c d t C$ genes of three $H$. ducreyi strains by PCR. Lanes $\mathbf{1}, 5$ and $\mathbf{9}$, DNA standards $1500 \mathrm{~kb} ; \mathbf{2}-\mathbf{4}$, screening for $c d t A ; \mathbf{6}-\mathbf{8}$, screening for $c d t B ; \mathbf{1 0}-\mathbf{1 2}$, screening for $c d t C$. Lanes 2, $\mathbf{6}$ and 10, strain CCUG $7470 ; 3,7$ and 11, a patient isolate; $\mathbf{4 , 8}$ and 12, strain CCUG 4438. 
Table 2. Presence of $c d t A B C$ and cytotoxic activity of $100 \mathrm{H}$. ducreyi strains from culture collections and 50 A. actinomycetemcomitans strains from patients with periodontitis

\begin{tabular}{lcc}
\hline & $\begin{array}{c}\text { Number of strains }(\mathrm{n}=50) \text { with } \\
\text { cytotoxic titre }\end{array}$ \\
\cline { 2 - 3 } Presence of gene cluster & $<100$ & $\geqslant 100$ \\
\hline H. ducreyi & & 0 \\
Cdt $A B C(-)$ & 18 & 32 \\
Cdt $A B C(+)$ & 0 & 0 \\
A. actinomycetemcomitans & & \\
Cdt $A B C(-)$ & 7 & 43 \\
Cdt $A B C(+)$ & 0 & \\
\hline
\end{tabular}

patients with genital ulcers, five did not have detectable $c d t A, B, C$ genes and the sonicates from these strains were not toxic to HEp-2 cells (titre $<1$ in 100). Of the remaining strains, 24 possessed all three $c d t$ genes and had cytotoxic activity $\geqslant 1$ in 100 . The percentage of fresh $H$. ducreyi isolates possessing all three $c d t A B C$ genes can be calculated to be $c .83 \%$, which is similar in frequency to the sample of $H$. ducreyi strains obtained from the culture collections $(82 \%)$. The similar prevalence of $c d t A B C$ genes in strains exposed to several culture passages and the fresh isolates indicates that the strains lacking these genes also occur naturally.

Prevalence of cdtABC genes and toxic activity in $A$. actinomycetemcomitans strains

The PCR method, with the same primers as for $H$. ducreyi, was employed to detect $c d t A, c d t B$ and $c d t C$ genes in $50 \mathrm{~A}$. actinomycetemcomitans strains. All 50 sonicates were tested for cytotoxic activity on HEp-2 cells. Forty-three $(86 \%)$ of 50 strains possessed all the three $c d t A B C$ genes and manifested cytotoxic activity of $>1$ in 100 (Table 2) indicating that the percentage of $c d t A B C$-positive $A$. actinomycetemcomitans strains from patients with periodontitis was similar to that of H. ducreyi strains.

\section{Comparison of cdtABC genes from various $H$. ducreyi strains}

The nucleotide sequences of the $c d t A B C$ gene cluster from four $H$. ducreyi strains (7470, 181, WPB 506 and PU1) isolated in different geographic locations were determined. The nucleotide sequences of the $c d t A$ and $c d t B$ ORFs from all four strains were identical and were also identical to those of four other $H$. ducreyi strains described previously [10]. Among the $c d t C$ ORFs, a single nucleotide change was found in one of the four strains analysed in this study. At position 2195 (based on the nucleotide sequence of the $H$. ducreyi strain 35000 cdtABC genes deposited in GenBank as accession no. U53215), the $c d t C$ ORF of strain 7470 had a $G$ in place of an $A$. This single nucleotide change resulted in the conservative substitution of valine for isoleucine at position 161 in the amino acid sequence of the cdtC protein.

\section{Discussion}

The production of a CDT has been reported as a potential virulence factor of some gram-negative organisms including $H$. ducreyi. These CDTs inhibit cell proliferation and cause cell death in many cultured human cells, including normal human keratinocytes, fibroblasts and immune cells $[12,13]$. However, the involvement of the toxin in the pathogenesis of chancroid has not yet been shown. Both in the temperature-dependent rabbit model and in the human model for chancroid, $H$. ducreyi strains with a mutation in the $C D T$ genes were shown to be as virulent as their isogenic parent strains [34, 35]. However, these models do have limitations; animal cells are known to be not sensitive or less sensitive to HdCDT than human cells and, therefore, the pathogenesis in these rabbits could be different from that in man. In the human experimental model of $H$. ducreyi infection, only the primary stages of chancroid can be studied, i.e., the development of a pustule.

Eighty-nine of $100 \mathrm{H}$. ducreyi strains from different geographic areas were reported to have cytotoxic activity according to the criteria used in that study [33]. The present study demonstrates the presence of $c d t A B C$ genes in $82 \%$ of $H$. ducreyi strains, which correlates with cytotoxic activity. The presence of low cytotoxic activity in some previously reported strains [33], in which the $c d t A B C$ genes are absent, was probably due to non-specific action of other bacterial components in sonicates on HEp-2 cells.

In the present study, among the 12 ORFs from four $H$. ducreyi strains, there was only a single nucleotide difference. This same single nucleotide change was found in the $c d t C$ ORF of strain RO18, one of the four additional $H$. ducreyi strains characterised previously [10]. Therefore, among the $c d t A B C$ ORFs from eight $H$. ducreyi strains, there was only a single nucleotide change and this occurred in just two strains. The conservation of the nucleotide sequence of the $c d t A B C$ genes among $H$. ducreyi strains is very striking. These data reinforce the conservation of this gene cluster among strains of this pathogen.

The origin of this highly conserved $c d t A B C$ gene cluster in $H$. ducreyi is unknown, but it must be noted that genes or incomplete ORFs that encode predicted proteins likely to function in transposition or recombination were detected within $3 \mathrm{~kb}$ on either side of the $c d t A B C$ gene cluster [10]. These include a partial ORF encoding a predicted protein with $36 \%$ identity to a staphylococcal transposase and a complete ORF encoding a predicted protein $58 \%$ identical to a transposon recombinase. These findings raise the 
possibility that the $c d t A B C$ gene cluster was introduced into $H$. ducreyi from another organism.

CDT inhibits cell division and this mechanism may be important in the development of chancroid ulcers or mucosal lesions seen in periodontitis by inhibiting the proliferation of epithelial cells, delaying the healing process (re-epithelialisation) or hampering immunological responses which are important for both healing and immunity. Thus, the clinical picture of infection with CDT-producing strains may be more severe than that with strains lacking the CDT.

In summary, the majority of $H$. ducreyi and $A$. actinomycetemcomitans isolates $(82 \%$ and $86 \%$, respectively) possess the $c d t A B C$ genes encoding CDT. The $c d t A B C$ genes are highly conserved among $H$. ducreyi strains.

We thank Dr Mikael Lebens for revision of the manuscript. This work was supported by the Swedish Agency for Research Cooperation with Developing Countries (SIDA/SAREC), Swedish Medical Research Council (grant 12630) and US Public Health service grant no. AI32011 to E.J.H.

\section{References}

1. De Schryver A, Meheus A. Epidemiology of sexually transmitted diseases: the global picture. Bull World Health Organ 1990; 68: 639-654.

2. DiCarlo RP, Armentor BS, Martin DH. Chancroid epidemiology in New Orleans men. J Infect Dis 1995; 172: 446-452.

3. Ortíz-Zepeda C, Hernández-Pérez E, Marroquín-Burgos R. Gross and microscopic features in chancroid: a study in 200 new culture-proven cases in San Salvador. Sex Transm Dis 1994; 21: 112-117.

4. Trees DL, Morse SA. Chancroid and Haemophilus ducreyi: an update. Clin Microbiol Rev 1995; 8: 357-375.

5. Greenblatt RM, Lukehart SA, Plummer FA et al. Genital ulcerations as a risk factor for human immunodeficiency virus infection. AIDS 1988; 2: 47-50.

6. Telzak EE, Chiasson MA, Bevier PJ, Stoneburner RL, Castro KG, Jaffe HW. HIV-1 seroconversion in patients with and without genital ulcer disease. A prospective study. Ann Intern Med 1993; 119: 1181-1186.

7. Purvén M, Lagergård T. Haemophilus ducreyi, a cytotoxinproducing bacterium. Infect Immun 1992; 60: 1156-1162.

8. Lagergård T, Purvén M, Frisk A. Evidence of Haemophilus ducreyi adherence to and cytotoxin destruction of human epithelial cells. Microb Pathog 1993; 14: 417-431.

9. Lagergård T. Haemophilus ducreyi; pathogenesis and protective immunity. Trends Microbiol 1995; 3: 87-92.

10. Cope LD, Lumbley S, Latimer JL et al. A diffusible cytotoxin of Haemophilus ducreyi. Proc Natl Acad Sci USA 1997; 94: 4056-4061.

11. Cortes-Bratti $\mathrm{X}$, Chaves-Olarte $\mathrm{E}$, Lagergård $\mathrm{T}$, Thelestam $\mathrm{M}$. The cytolethal distending toxin from the chancroid bacterium Haemophilus ducreyi induces cell-cycle arrest in the G2 phase. $J$ Clin Invest 1999; 103: 107-115.

12. Gelfanova V, Hansen EJ, Spinola SM. Cytolethal distending toxin of Haemophilus ducreyi induces apoptic death of Jurkat $\mathrm{T}$ cells. Infect Immun 1999; 67: 6394-6402.

13. Svensson LA, Tarkowski A, Thelestam M, Lagergård T. The impact of Haemophilus ducreyi cytolethal distending toxin on cells involved in immune response. Microb Pathog (in press).

14. Pickett CL, Whitehouse CA. The cytolethal distending toxin family. Trends Microbiol 1999; 7: 292-297.

15. Cortes-Bratti X, Karlsson C, Lagergård T, Thelestam M, Frisan $\mathrm{T}$. The Haemophilus ducreyi cytolethal distending toxin induces cell cycle arrest and apoptosis via the DNA damage checkpoint pathways. J Biol Chem 2001; 276: 5296-5302.

16. Scott DA, Kaper JB. Cloning and sequencing of the genus encoding Escherichia coli cytolethal distending toxin. Infect Immun 1994; 62: 244-251.

17. Pickett CL, Cottle DL, Pesci EC, Bikah G. Cloning, sequencing, and expression of the Escherichia coli cytolethal distending toxin genes. Infect Immun 1994; 62: 1046-1051.

18. Comayras C, Tasca C, Pérès SY, Ducommun B, Oswald E, De Rycke J. Escherichia coli cytolethal distending toxin blocks the HeLa cell cycle at the $\mathrm{G}_{2} / \mathrm{M}$ transition by preventing cdc2 protein kinase dephosphorylation and activation. Infect Immun 1997; 65: 5088-5095.

19. Okuda J, Fukumoto M, Takeda Y, Nishibuchi M. Examination of diarrheagenicity of cytolethal distending toxin: suckling mouse response to the products of the $c d t A B C$ genes of Shigella dysenteriae. Infect Immun 1997; 65: 428-433.

20. Johnson WM, Lior H. A new heat-labile cytolethal distending toxin (CLDT) produced by Campylobacter spp. Microb Pathog 1988; 4: 115-126.

21. Pickett CL, Pesci EC, Cottle DL, Russell G, Erdem AN, Zeytin H. Prevalence of cytholethal distending toxin production in Campylobacter jejuni and relatedness of Campylobacter sp. $c d t B$ genes. Infect Immun 1996; 64: 2070-2078.

22. Whitehouse CA, Balbo PB, Pesci EC, Cottle DL, Mirabito PM, Pickett CL. Campylobacter jejuni cytolethal distending toxin causes a $\mathrm{G}_{2}$-phase cell cycle block. Infect Immun 1998; 66: 1934-1940.

23. Young VB, Knox KA, Schauer DB. Cytolethal distending toxin sequence and activity in the enterohepatic pathogen Helicobacter hepaticus. Infect Immun 2000; 68: 184-191.

24. Mayer MPA, Bueno LC, Hansen EJ, DiRienzo JM. Identification of a cytolethal distending toxin gene locus and features of a virulence-associated region in Actinobacillus actinomycetemcomitans. Infect Immun 1999; 67: 1227-1237.

25. Shenker BJ, Hoffmaster RH, McKay TL, Demuth DR Expression of the cytholethal distending toxin (Cdt) operon in Actinobacillus actinomycetemcomitans: evidence that the $\mathrm{CdtB}$ protein is responsible for $\mathrm{G} 2$ arrest of the cell cycle in human T cells. J Immunol 2000; 165: 2612-2618.

26. Sugai $\mathrm{M}$, Kwamoto $\mathrm{S}$, Pérès $\mathrm{Y}$ et al. The cell cycle-specific growth-inhibitory factor produced by Actinobacillus actinomycetemcomitans is cytolethal distending toxin. Infect Immun 1998; 66: 5008-5019.

27. Elwell CA, Dreyfus LA. DNase I homologous residues in CdtB are critical for cytholethal distending toxin-mediated cell cycle arrest. Mol Microb 2000; 37: 952-963.

28. Lara-Tejero M, JE Galán. A bacterial toxin that controls cell cycle progression as a deoxyribonuclease I-like protein. Science 2000; 290: 354-357.

29. Frisk A, Lebens M, Johansson C, Ahmed H, Svensson L, Ahlman K, Lagergård $\mathrm{T}$. The role of different components from the Haemophilus ducreyi cytolethal distending toxin in generation of cell toxicity. Microb Pathog (in press).

30. Purdy D, Buswell CM, Hodgson AE, McAlpine K, Henderson I, Leach SA. Characterisation of cytolethal distending toxin (CDT) mutants of Campylobacter jejuni. J Med Microbiol 2000; 49: 473-479.

31. Stevens MK, Latimer JOL, Lumbley SR et al. Characterization of a Haemophilus ducreyi mutant deficient in expression of the cytolethal distending toxin. Infect Immun 1999; 67: 3900-3908.

32. Young RS, Fortney KR, Gelfanova V et al. Expression of cytolethal distending toxin and hemolysin is not required for pustule formation by Haemophilus ducreyi in human volunteers. Infect Immun 2001; 69: 1938-1942.

33. Purvén M, Falsen E, Lagergård T. Cytotoxin production in 100 strains of Haemophilus ducreyi from different geographic locations. FEMS Microbiol Lett 1995; 129: 221-224.

34. Ahmed HJ, Borrelli S, Jonasson $\mathrm{J}$ et al. Monoclonal antibodies against Haemophilus ducreyi lipooligosaccharide and their diagnostic usefulness. Eur J Clin Microbiol Infect Dis 1995; 14: $892-898$

35. Sambrook J, Fritsch EF, Maniatis T. Analysis of genomic DNA by Southern hybridization. In: Molecular cloning - a laboratory manual, 2nd edn, vol 2. Cold Spring Harbor, NY, Cold Spring Harbor Laboratory Press. 1989: 9.31-9.46. 